\title{
Plankton dynamics and larval herring growth, drift and survival in a frontal area
}

\author{
Thomas Kiørboe $^{1}$, Peter Munk ${ }^{1}$, Katherine Richardson ${ }^{1}$, Villy Christensen ${ }^{2}$, \\ Helge Paulsen ${ }^{2}$
}

${ }^{1}$ Danish Institute for Fisheries and Marine Research, Charlottenlund Castle, DK-2920 Charlottenlund, Denmark

${ }^{2}$ Danish Institute for Fisheries and Marine Research, The North Sea Center, DK-9850 Hirtshals, Denmark

\begin{abstract}
Horizontal and temporal variations in abundance and productivity of phyto- and zooplankton were studied in a frontal area in the NW North Sea during September and October 1985. In addition, distributions of several cohorts of herring larvae found in this area were monitored and larval growth and survival estimated. Phytoplankton biomass and productivity as well as copepod productivity peaked in the transitional zone between isothermal and temperature-stratified water. Copepod egg production was observed to increase markedly subsequent to a severe storm. The frontal region, then, was identified as particularly productive in terms of larval herring food (immature copepods), and frequent autumn storms may also stimulate the production of larval food. Six larval cohorts were identified within the study area, all with estimated instantaneous mortalities of $<0.05 \mathrm{~d}^{-1}$. Upon hatching in August/September, larvae patches drifted towards the south until the end of the study in late October. Throughout this period, larvae tended to be retained within the frontal region. Crossfrontal transects revealed peak abundances of larvae in transitional water concurrent with peak copepod production. In spite of this, larval growth was suboptimal and limited by food availability. It is shown that larval feeding was of the same order of magnitude as production of larval food and it is suggested that competition for food in the larval stage contributes to density-dependent growth, survival and, hence, recruitment.
\end{abstract}

\section{INTRODUCTION}

Processes occurring during the larval stage have long been supposed to be important determinants of yearclass strength of Atlantic herring Clupea harengus. As early as 1914, Hjort advocated the 'critical period' concept which maintains that herring larval survival and hence recruitment are primarily determined by food limitation in the early larval stage. This hypothesis has subsequently been modified and developed by a number of workers.

Cushing (1975) presented the 'match-mismatch' hypothesis in which the success or failure of a year class is dependent upon the match or mismatch between the timing of larval emergence and plankton blooms. Following a similar line of reasoning, Lasker $(1975,1981)$ developed the 'stable ocean hypothesis', which proposes that fish larvae (specifically Engraulis mordax) are dependent upon food patches that develop during periods of low mixing intensity. Implicit in this hypothesis is that while larval survival and hence year class strength are dependent upon food availability, the latter is ultimately determined by the frequency and timing of storm events.

Lambert (1984) explained time segregation between herring larvae cohorts as an adaptation to food limitation as time separation permits larval cohorts to exploit virtually independent food sources and, thus, limits intraspecific competition for food. Following the arguments of Ricker \& Foerster (1948) and Sheperd \& Cushing (1980), Houde (1987) showed that, even though food limitation may not influence instantaneous larval mortality, reported variations in larval herring growth rates may lead to substantial variation in cumulative larval mortality and a 10 to 100 -fold variation in survivorship at metamorphosis. Thus, variations in larval food availability may, potentially, contribute to recruitment variability, while competition for food may lead to density-dependent regulation of recruitment. Despite the numerous theories relating food availability, larval survival and herring recruitment, evidence from nature of food limitation and its possible effects on fish larval growth and survival is limited (e.g. Frank \& Leggett 1986). 
Recently, a number of workers have suggested that the interactions between larval processes and hydrographic events can play an important role in determining recruitment. Iles \& Sinclair $(1982,1985)$ hypothesized that the size of unexploited herring stocks is determined by the size of the larvae 'retention area' and that the carrying capacity of the retention area is determined by its integrity (i. e. ability to retain larvae) rather than the availability of larval food. Thus, the retention area concept implies that larvae, upon hatching, are being retained in a specific area characterized by certain oceanographic properties, that interannual variability in larval mortality and recruitment is controlled by variable losses of larvae from this area, and that the production of food does not limit larval survival or influence recruitment. To illustrate their theory, Iles \& Sinclair $(1982,1985)$ drew on the association of herring spawning grounds and tidally well-mixed areas bounded by transition zones (fronts), separating stratified and mixed waters, both in the Georges Bank area and along the eastern coast of the British Isles, and identified these areas as retention areas.

The retention area concept has been criticized by Cushing (1986) in that herring larvae in the North Sea often hatch outside the period of water column stratification, and because larval drift across the North Sea prior to metamorphosis has been demonstrated. Nevertheless, the association of herring spawning grounds with hydrographic discontinuities around the British Isles is striking. Cushing (1986) also acknowledged this association and speculated that the size of the gravel in the sediments near hydrographic transition zones may make these areas particularly suitable as herring spawning sites. The ramifications, if any, of this association between spawning grounds and hydrographic transition zones for larval ecology are, as yet, unknown. However, evidence is accumulating which suggests that the interaction between larval biology and hydrographic features may be a determining factor in larval survival and, hence, recruitment.

Heath \& MacLachlan (1987) demonstrated transport of newly hatched herring larvae northwards from west of the Isles of Uist and Benbecula in the outer Hebrides (NW Scotland) along a frontal boundary separating Atlantic and coastal waters. Thus, it is apparently along this frontal boundary that larvae hatching to the west of Scotland are transported to the North Sea. While larval transport processes appear to be more complex to the North of Scotland (Cape Wrath area; Heath et al. 1987), they can also be related to the local current conditions and the occurrence of a frontal system.

The importance of frontal regions in the transport of young herring larvae has also been suggested in a study by the present authors carried out in the Buchan area, east of Scotland, in September 1984. In that study, centers of larval distribution were located in a thermal front running approximately parallel to the Scottish coast (Richardson et al. 1986a). Munk et al. (1986) identified 3 cohorts of larvae in this distribution and reported movement in a south/southeasterly direction for all cohorts. In spite of this drift, centers of larval distribution remained associated with the frontal region (Richardson et al. 1986a), Studies of plankton dynamics in the area indicated that primary production (Richardson et al. 1986b) and secondary production (Kiørboe \& Johansen 1986) peaked in frontal waters. Thus, centers of larval distribution were associated with the most abundant food supply. Nevertheless, larval growth was suboptimal and limited by food availability or production (Kiørboe \& Johansen 1986).

The purpose of the present study was to continue investigations into the interaction between herring larval ecology and hydrographic features/events. The study area was, again, the Buchan area off the east coast of Scotland. However, the investigations were carried out approximately 1 mo later (mid-September to mid-October), a period in which the thermal front is undergoing erosion due to autumn storms. The specific aims of the study were to examine: (1) the distribution and movements of larvae in relation to hydrographic features $_{i}(2)$ the dynamics (distribution and production) of the plankton encountered by the larvae in relation to horizontal and temporal variation in hydrodynamics; (3) the growth within different cohorts of larvae, and the spatial and temporal segregation between cohorts; and, finally, (4) to evaluate the food demands of the larvae and consider the possibility of food limitation and food competition.

\section{MATERIALS AND METHODS}

Sampling. The study was carried out from RV 'Dana' (Danish Fisheries Ministry) from 16 September to 19 October 1985. Herring Iarvae were collected using a Gulf III sampler towed obliquely at $5 \mathrm{kn}$ to within $5 \mathrm{~m}$ of the bottom. The sampler was continuously lowered/ raised at a speed of $10 \mathrm{~m}$ per $1.5 \mathrm{~min}$. Mesh size was $250 \mu \mathrm{m}$ and samples were preserved in $4 \%$ formaldehyde. Standard lengths of preserved larvae were measured to the nearest mm. Full description of the methods employed can be found in Christensen et al. (1983). The Gulf was fitted with an Electro Lloyd (CTPS) CTD and data received via a cored towing cable. Temperature and salinity were recorded using a Neil Brown CTD. Samples for calibration of the salinity probe were taken at varying depths at stations along 2 transects through the frontal region.

A stratification parameter was calculated for each station after Simpson (1981). This parameter, $\Phi$, gives a 
measure of the mechanical work, in $\mathrm{J} \mathrm{m}^{-3}$, required to mix the water column. Chlorophyll a fluorescence was measured with a $Q$ instruments fluorometer. Calibration of the fluorometer was made by making spectrophotometric determination of chlorophyll in extractions (90\% acetone) from 3 depths at selected stations. Samples for primary productivity estimates were taken from $15 \mathrm{~m}$. Procedures and calculations used in chlorophyll and primary production determinations are fully described in Richardson (1985). Productivity samples were kept in subdued light, filtered through a $200 \mu \mathrm{m}$ mesh and transferred to $25 \mathrm{ml}$ acid-washed Pyrex bottles. Four $\mu \mathrm{Ci}$ of a $\mathrm{NaH}^{14} \mathrm{CO}_{3}$ solution were added to each bottle. The ${ }^{14} \mathrm{C}$ addition was checked by taking $50 \mu \mathrm{l}$ subsamples of the incubation media and adding them to $500 \mu \mathrm{l} \beta$-phenylethylamine. These were stored for later counting. Samples were attached to a rotating wheel and incubated for $2 \mathrm{~h}$ at ambient seawater temperature $\pm 2 \mathrm{C}^{\circ} \cdot{ }^{14} \mathrm{C}$ incorporation at 7 photon flux densities from 0 to $320 \mu$ mole $\mathrm{m}^{-2} \mathrm{~s}^{-1}$ was determined.

Depth-integrated samples for determination of zooplankton composition and biomass were collected by a submersible pump (230 $\mathrm{l} \mathrm{min}^{-1}$ ) lowered through the water column at $10 \mathrm{~m} \mathrm{~min}^{-1}$. The water was pumped on deck via a 2 inch $(5 \mathrm{~cm})$ diameter hose and successively filtered on 200, 100 and $30 \mu \mathrm{m}$ mesh sieves. Samples were preserved in $4 \%$ buffered formaldehyde. Zooplankters in the samples (or subsamples for the finer fractions) were later counted, identified to species (or genus) and, in the case of copepods, aged and sexed i. e. egg, INí-IIII, INIV-VI, Cí-III, CIV-V and adult male or female). Abundance data for copepods were converted to biomass by using species-specific weights of eggs, nauplii and copepodite stages as in Kiørboe \& Johansen (1986). Egg production rates for the calanoid copepod Acartia tonsa were determined in shipboard experiments by the incubation technique described by Kiørboe et al. (1985). Adult females were collected in the upper mixed layer using a WP-2 opening-closing net. Fertilized females were immediately removed from the zooplankton mixture and 3 to 6 individuals were placed in each of six $600 \mathrm{ml}$ bottles containing water from the collection depth. These were incubated at in situ temperature $\left( \pm 1 \mathrm{C}^{\circ}\right)$ for $24 \mathrm{~h}$. At the termination of the incubation, numbers of eggs spawned (including empty egg shells) were determined.

Four surveys of larval distribution were carried out during the study period. These surveys ( 1 to 4 ) and data from an earlier survey (here called 0 ) carried out by DAFS Marine laboratory, Aberdeen, UK, were included in the analysis. A description of the surveys is given in Table 1. The total number of larvae caught and a length distribution of a subsample of 80 to 150 larvae were determined for each sample.

In addition to the surveys of larval distribution, a transect consisting of 12 stations and intersecting the frontal region $\left(56^{\circ} 08^{\prime} \mathrm{N}, 00^{\circ} 40^{\prime} \mathrm{E}\right.$ to $56^{\circ} 45^{\prime} \mathrm{N}$, $01^{\circ} 50^{\prime} \mathrm{W}$ ) was surveyed twice (12 to 13 and 16 to 17 October). These transect surveys included measurements of phytoplankton and zooplankton biomass and productivity as well as hydrography and herring larval abundance.

Data analysis. To estimate growth, survival and drift of separate larval cohorts we used the following approach. On the basis of the spatial distribution patterns (determined during Survey 0), 5 centres of larval distribution were identified (Fig. 1). There was some spatial overlap between the cohorts, which revealed itself as bimodal length distributions at many individual stations. In order to decide which cohorts were represented at a given station, larval length distributions at neighboring stations were compared. The main identification was made by comparison of $\mathrm{N}-\mathrm{S}$ transects (see Fig. 2 for an example) whereafter the findings were cross-checked by comparison in an E-W direction. This N-S, E-W comparison revealed an additional cohort of larvae between Cohorts 6 and 3 on Survey 0 (Cohort 1).

The analysis was repeated for the subsequent surveys. There was normally consistency between the

Table 1. Description of surveys used in the analysis. Survey 0 was made from RV 'Clupea', DAFS Marine Laboratory, Aberdeen; Surveys 1 to 4 from RV 'Dana'. Northern, southern and eastern limits of the area sampled in each survey are given by latitudes and longitudes; western limit follows the coastline in every case. Basic sampling grid was $10 \times 10 \mathrm{n}$ mile. In some cases, additional stations have been sampled to give an approximate distance between stations of $7 \mathrm{n}$ mile

\begin{tabular}{|c|c|c|c|c|c|c|c|}
\hline \multirow[t]{2}{*}{ Survey } & \multirow{2}{*}{$\begin{array}{l}\text { Period of } \\
\text { sampling } \\
(1985)\end{array}$} & \multicolumn{3}{|c|}{ Area covered } & \multirow{2}{*}{$\begin{array}{c}\text { No. of } \\
\text { stations }\end{array}$} & \multicolumn{2}{|c|}{ Distance between stations ( $\mathrm{m}$ mile) } \\
\hline & & & & & & areas & areas \\
\hline 0 & $7-11$ Sep & $57^{\circ} 55^{\prime} \mathrm{N}$ & $56^{\circ} 05^{\prime} \mathrm{N}$ & $00^{\circ} 15^{\prime} \mathrm{W}$ & 71 & 10 & 10 \\
\hline 1 & $16-21$ Sep & $57^{\circ} 55^{\prime} \mathrm{N}$ & $56^{\circ} 05^{\prime} \mathrm{N}$ & $00^{\circ} 15^{\prime} \mathrm{E}$ & 91 & 10 & 10 \\
\hline 2 & 23-28 Sep & $57^{\circ} 25^{\prime} \mathrm{N}$ & $56^{\circ} 05^{\prime} \mathrm{N}$ & $00^{\circ} 00^{\prime}$ & 113 & 7 & 7 \\
\hline 3 & $8-12$ oct & $57^{\circ} 15^{\prime} \mathrm{N}$ & $55^{\circ} 45^{\prime} \mathrm{N}$ & $00^{\circ} 30^{\prime} \mathrm{E}$ & 98 & 7 & 10 \\
\hline 4 & $17-19$ Oct & $56^{\circ} 55^{\prime} \mathrm{N}$ & $55^{\circ} 45^{\prime} \mathrm{N}$ & $00^{\circ} 30^{\prime} \mathrm{E}$ & 73 & 7 & 10 \\
\hline
\end{tabular}




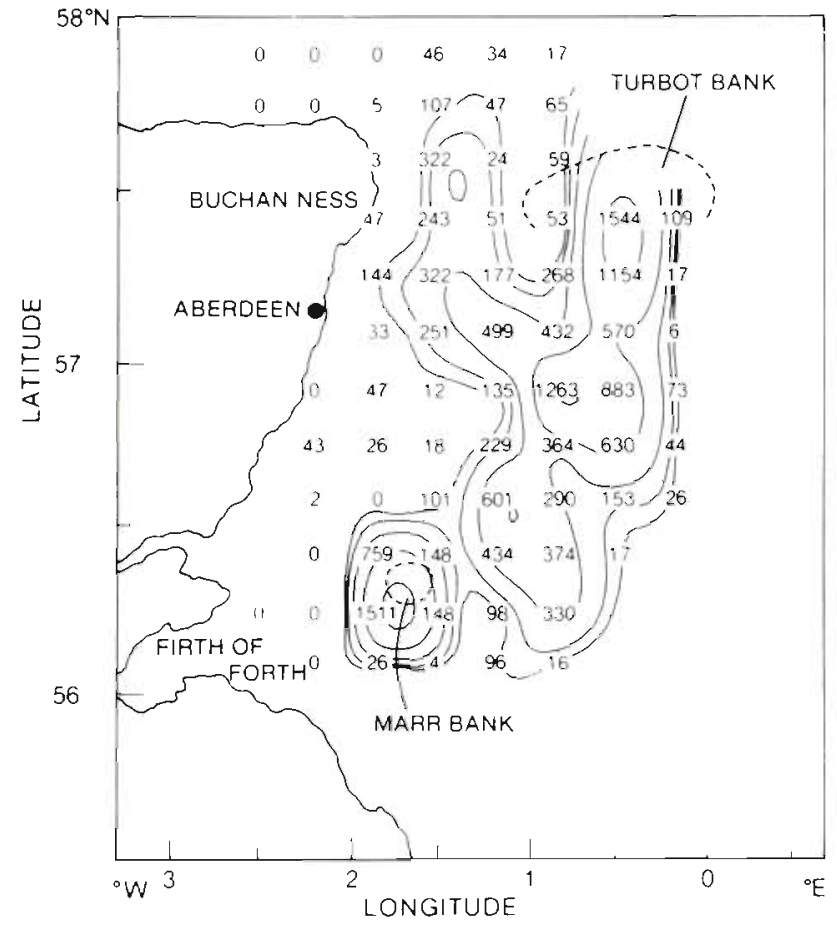

Fig. 1. Clupea harengus. Distribution of herring larvae east of Scotland during Survey 0, 7 to 11 September 1985. Figures show estimated larval abundances in numbers $\mathrm{m}^{-2}$. Contour lines have been drawn by the contouring procedure of SAS (Sas Institute Inc., North Carolina)

surveys in the sense that average larval length in any particular cohort increased over time and that the mutual positions between cohorts changed gradually (not abruptly) between surveys.

By this somewhat subjective analysis, the geo-

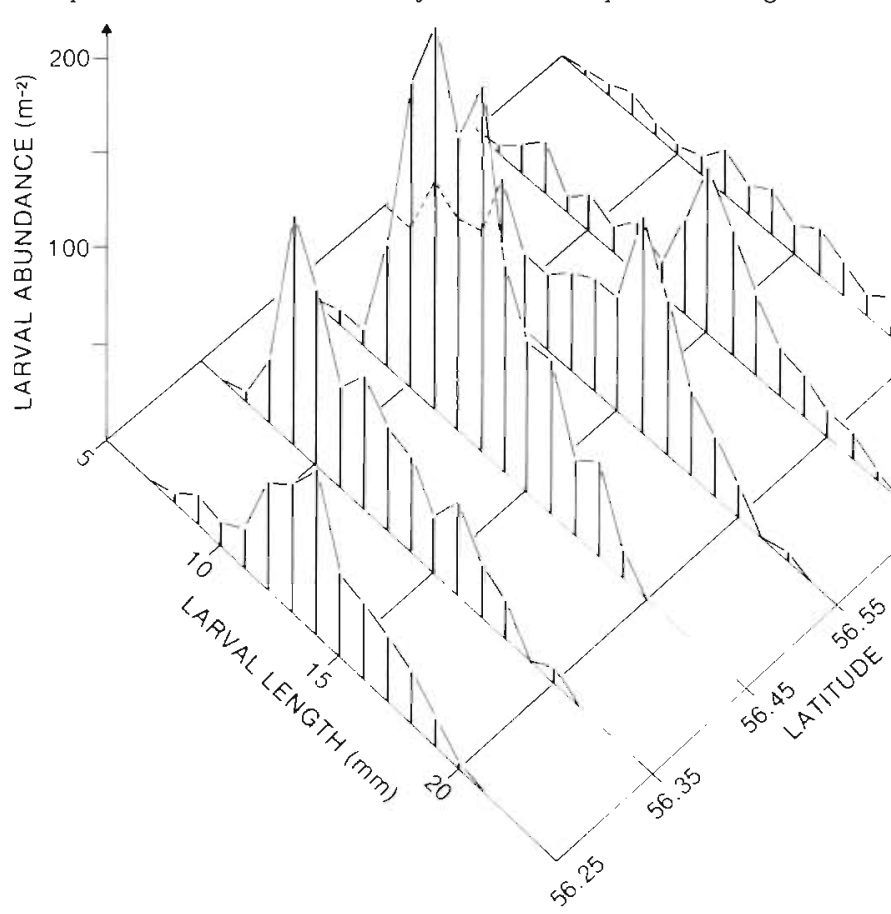

graphical distribution of all cohorts was identified for each survey. To separate larvae into cohorts at stations with bimodal length frequency distributions, these length distributions were fitted to the sum of 2 normal distributions by least square regression and the number of larvae belonging to each cohort estimated. Finally, the geographical and numerical distribution of each cohort was plotted and contour lines drawn.

Cohort centres were defined as the weighted average position of the 4 stations with peak larval abundance. Average time-specific lengths of larvae in each cohort were calculated by fitting a length frequency distribution for the central stations to a compound normal distribution. The mean length of the most abundant group was considered representative for the cohort.

The total abundance of larvae in each cohort was estimated by taking the mean abundance in each $10 \times 10 \mathrm{n}$ mile square and summing up for all squares where the cohort was found.

\section{RESULTS}

\section{Hydrography}

During all surveys, a density discontinuity was observed in which mixed water occurred to the west and stratified water to the east of ca $1^{\circ} \mathrm{W}$ (Fig. 3). On 3 of 4 surveys (Fig. 3a, c, d), the stability isopleths approach the coast in the northern and southern regions of the study area in a manner similar to that predicted by the Pingree \& Griffiths (1978) model. The position of the front was similar to that observed in 1984 by Richardson et al. (1986a). The observed front manifested itself primarily as a bottom temperature phenomenon (Fig. 4)

Although the position of the front remained fairly constant at between $0^{\circ} 40^{\prime} \mathrm{W}$ and $1^{\circ} \mathrm{W}$ throughout the study period, the degree of stratification could be seen to erode. Comparing the 2 transects, we calculated that

Fig. 2. Clupea harengus. Example of a length frequency distribution along a $\mathrm{N}-\mathrm{S}$ transect (longitude $1.30^{\circ} \mathrm{W}$ on Survey 2). Larval abundance in no. $\mathrm{m}^{-2}$ for each millimeter interval. Latitude $(\mathrm{N})$ is presented in degrees and minutes

he surface-to-bottom temperature difference in frontal waters (Stns 4 to 7 ) decreased by up to $0.25 \mathrm{C}^{\circ}$ between the first and second transects. In stratified waters, the surface to bottom temperature difference decreased by ca $0.1 \mathrm{C}^{\circ}$ during the same period. 


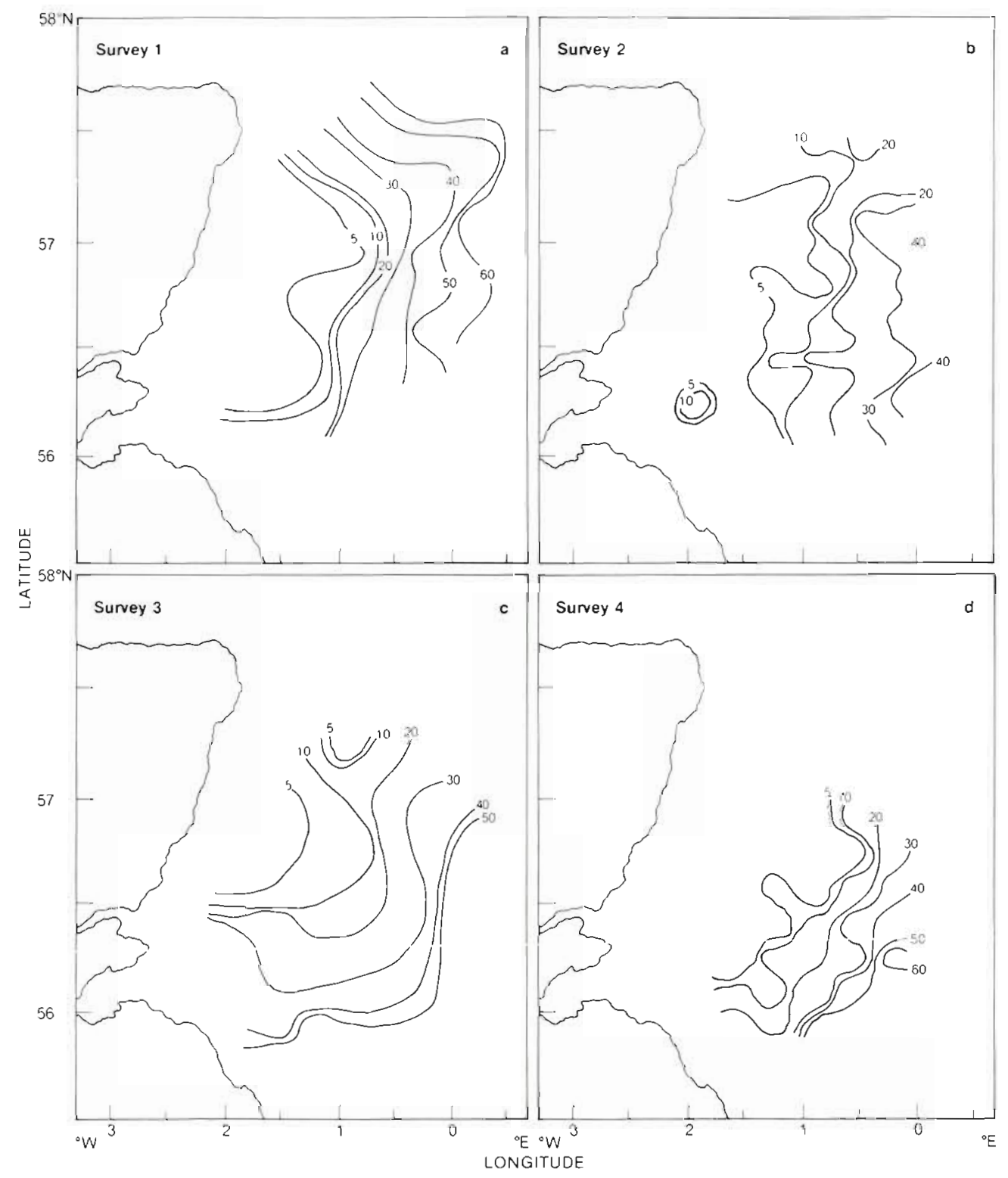

Fig. 3. Isolines showing distribution of the stratification parameter $\Phi\left(\mathrm{J} \mathrm{m}^{-3}\right)$ for Surveys 1 to 4

\section{Chlorophyll distribution and primary production}

The maximum chlorophyll a concentration observed during the study was $1.8 \mu \mathrm{g} \mathrm{l}^{-1}$. Chlorophyll maxima occurred at the surface in frontal and stratified waters near the front (Fig. 4). Chlorophyll concentrations were more or less homogenously distributed in the upper 15 to $20 \mathrm{~m}$ of the water column in the frontal/stratified waters and down to the bottom in isothermal waters.

Primary production varied significantly but appeared to be highest (up to $550 \mathrm{mg} \mathrm{C} \mathrm{m} \mathrm{m}^{-2} \mathrm{~d}^{-1}$ ) both in and seaward of the front (Fig. 4).

\section{Zooplankton distribution}

The zooplankton was dominated by copepods. Numerically, the planktonic copepods were dominated by Oithona sp. followed by (in decreasing order of female abundance) Acartia spp., Para-/Pseudocalanus sp., Calanus finmarchicus, Centropages typicus, Microcalanus sp. and Metridia lucens. There were no marked trends in species composition along or between the transects.

The distribution of total copepod biomass (including eggs, nauplii, copepodites and adults) showed no 
TRANSECT 1

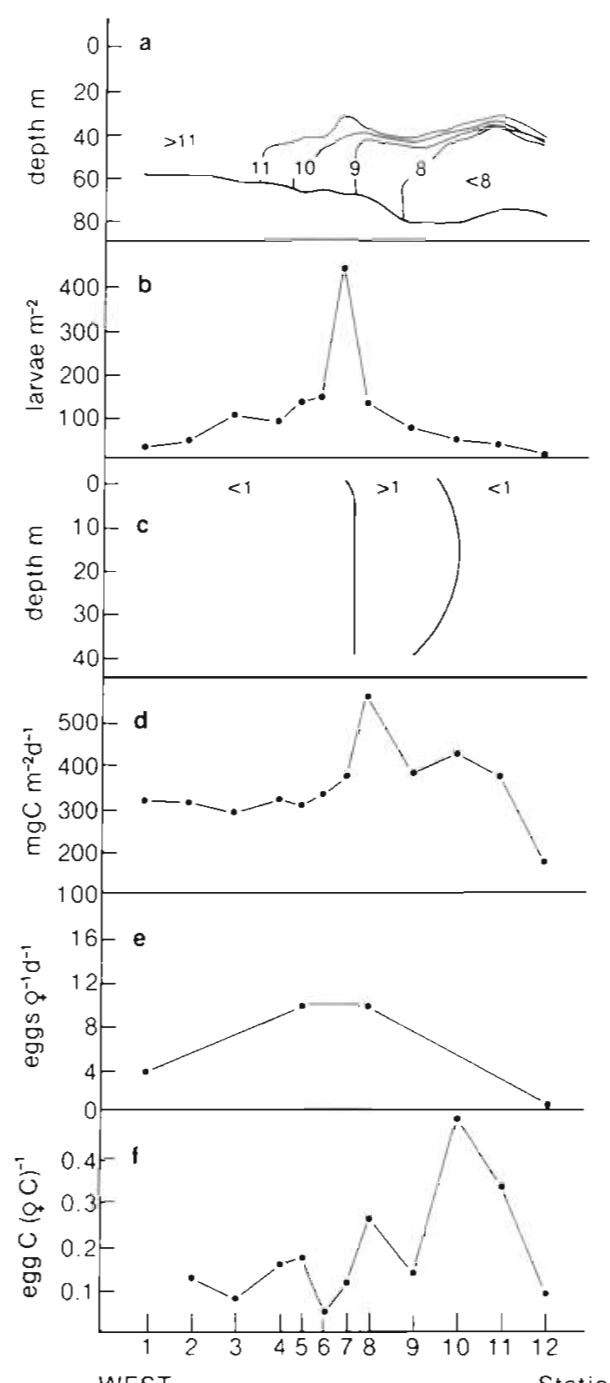

TRANSECT 2
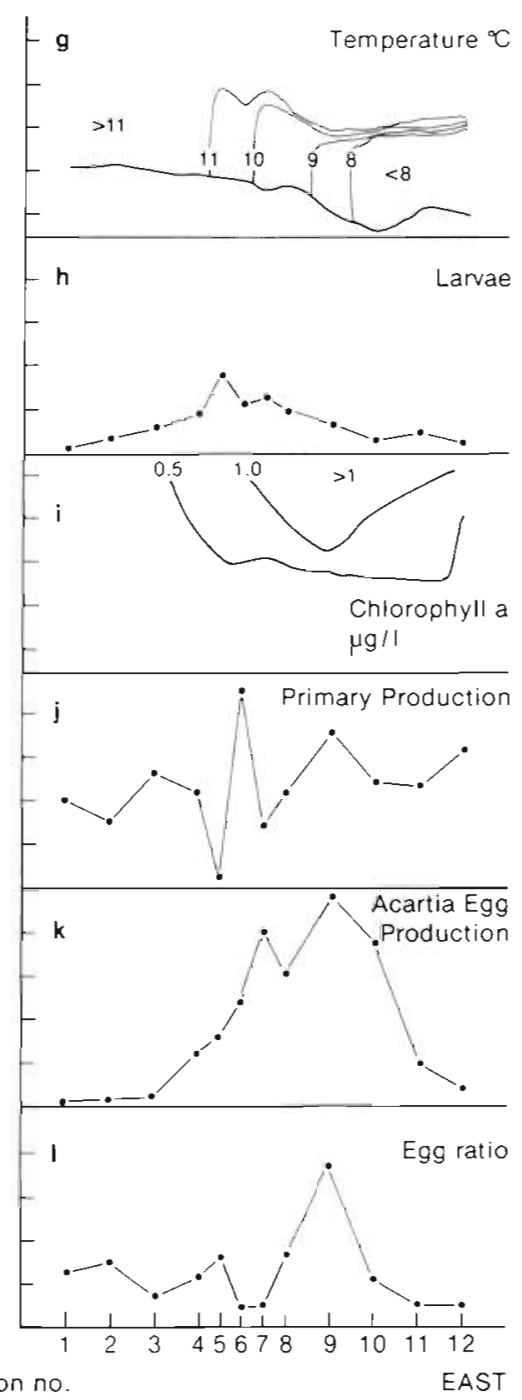

Fig. 4. Data from 2 cross-frontal transects $\left(56^{\circ} 08^{\prime} \mathrm{N}, 00^{\circ} 40^{\prime} \mathrm{E}\right.$ to $56^{\circ} 45^{\prime} \mathrm{N}, 01^{\circ} 50^{\prime} \mathrm{W}$ ) sampled on 12 to 13 Oct (Transect 1$)$ and 16 to 17 Oct (Transect 2). $(\mathrm{a}, \mathrm{g})$ Temperature ${ }^{\circ} \mathrm{C} i(\mathrm{~b}, \mathrm{~h})$ larval herring distributions; $(\mathrm{c}, \mathrm{i})$ chlorophyll a $\left(\mu \mathrm{g} \mathrm{l}^{-1}\right)$; $\left(\mathrm{d}_{1}, \mathrm{j}\right)$ primary production ( $\left.m \mathrm{~m} \mathrm{~m}^{-2} \mathrm{~d}^{-1}\right)$; $(\mathrm{e}, \mathrm{k})$ Acartia tonsa egg production (eggs female $\left.\mathrm{e}^{-1} \mathrm{~d}^{-1}\right) ;(\mathrm{f}, \mathrm{l})$ biomass of copepod eggs ( $\mu \mathrm{g}$ C) divided by biomass of females ( $\mu \mathrm{g} \mathrm{C}$ ) in depth-integrated pump samples pooled for small-sized species (see text)

apparent relationship to either hydrographic features or chlorophyll distribution (Fig. 5). Copepod biomass was separated into 2 size fractions, 30 to $200 \mu \mathrm{m}$ and $>200 \mu \mathrm{m}$ (Fig. 5). The biomass in the 30 to $200 \mu \mathrm{m}$ fraction declined from between 1.5 and $3.5 \mathrm{mg} \mathrm{C} \mathrm{m}^{-3}$ during the first to between 0.8 and $2.6 \mathrm{mg} \mathrm{C} \mathrm{m}^{-3}$ during the second transect, whereas the biomass in fraction $>200 \mu \mathrm{m}$ increased from between 1.5 and 4.5 to between 1.7 and $7.5 \mathrm{mg} \mathrm{C} \mathrm{m}^{-3}$ from the first to the second transect. The increased biomass in the $>200 \mu \mathrm{m}$ fraction was caused by increased abundance of largesized stages of most species but particularly of Calanus finmarchicus. Since the 2 transects were separated by only $4 \mathrm{~d}$, this difference was probably caused by sampling different water masses rather than the growth of copepods from the small to the large fraction. The 30 to $200 \mu \mathrm{m}$ fraction comprised 31 to $52 \%(\overline{\mathrm{x}}=40 \%)$ during the first and 14 to $39 \%(\bar{x}=27 \%)$ of total copepod biomass during the second transect. During both transects, the proportion of copepod biomass comprised by the small $(30$ to $200 \mu \mathrm{m})$ fraction was inversely correlated to larval herring abundance $(r=-0.64, p<0.025$ and $r=-0.51, p<0.10$, respectively).

Among non-copepod zooplankters, only gastropods and bivalve veligers were of numerical importance. Both of these groups showed peak abundances concur- 

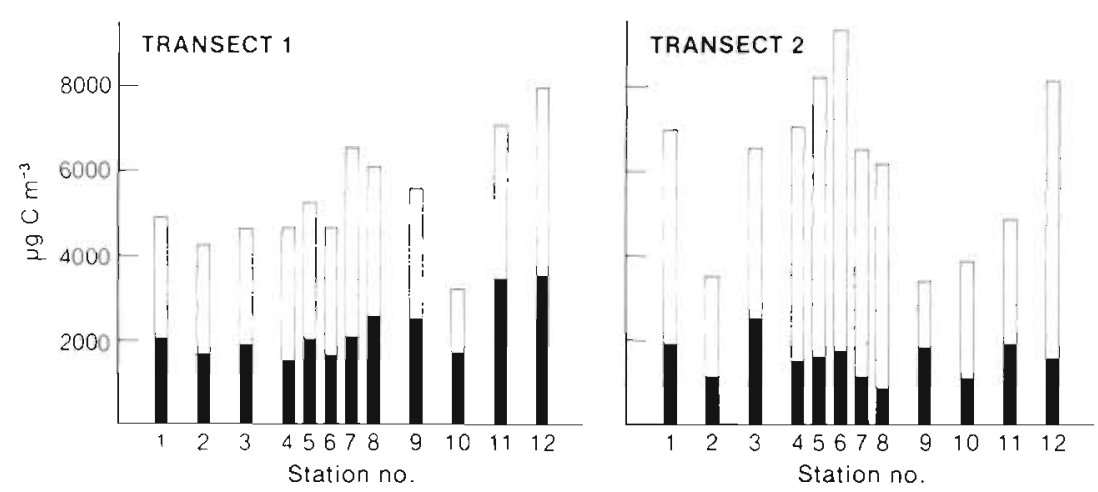

Fig. 5. Distribution of copepod biomass $\left(\mu \mathrm{g} \mathrm{C} \mathrm{m}^{-3}\right.$ ) along 2 transects. Copepod biomass in the $>200 \mu \mathrm{m}$ (open bars) and the 30 to $200 \mu \mathrm{m}$ (solid bars) fractions

rent with the chlorophyll maximum at Stn 8 and declined in on- as well as offshore directions (Fig. 6).

\section{Copepod egg production}

During the period 8 to 10 October, experimentally determined egg production rates of Acartia tonsa were low (less than 5 eggs female ${ }^{-1} \mathrm{~d}^{-1}$ ) and uncorrelated to the concentration of chlorophyll a (Fig. 7a, b). After a severe storm on 10 and 11 October (windspeeds up to $27 \mathrm{~m} \mathrm{~s}^{-1}$ were recorded in the Forties Area [57.00 N to $58.00 \mathrm{~N} ; 0.00 \mathrm{E}$ to $1.00 \mathrm{E}$ ] by the Royal Netherlands Meteorological Institute), the maximum determined egg production rates increased significantily fup to 20 eggs female $e^{-1} \mathrm{~d}^{-1}$ ), even though the concentration of chlorophyll a appeared to decrease slightly during this period. From $3 \mathrm{~d}$ after the storm, copepod egg production rates became strongly correlated to the concentration of chlorophyll a (Fig. 7c, d).

The 2 transects were surveyed after the storm and, in both cases, the experimentally determined egg production rates were low in mixed $\left(\Phi<10 \mathrm{~J} \mathrm{~m}^{-3}\right)$ and strongly stratified $\left(\Phi>60 \mathrm{~J} \mathrm{~m}^{-3}\right)$ water and peaked in the intermediate stratified water (Fig. 4).
Fig. 4 also shows the variation in the egg ratio leggcarbon/female-carbon in the depth-integrated samples) along the 2 transects, pooled for small species (i. e. Acartia spp., Para-/Pseudocalanus sp., Centropages typicus and Temora longicornis). In both instances, the egg ratio peaked in stratified water to the east of the peak in A. tonsa egg production rates. Low values of the ratio were found at the transitional stations and in mixed water.

\section{Distribution and drift of larvae}

Six distinct patches (Cohorts 1 to 6) of larvae were recognized (Fig. 8a to e). Cohorts 1 and 6 were found off Aberdeen, Cohort 2 in the Firth of Forth area (over Marr Bank) and Cohorts 3,4 and 5 in a large area extending to the south of Turbot Bank (ca $75 \mathrm{~km}$ east of Buchan Ness) (Fig. 1). Cohorts 3, 4 and 5 could only be discriminated on the basis of their spatial distributions (larval length increased gradually towards the south) and they are, therefore, treated as a single group in the contour plots of Fig. 8. Two additional patches of larvae, one in the northernmost and one in the southernmost part of the area, were recognized but only par-
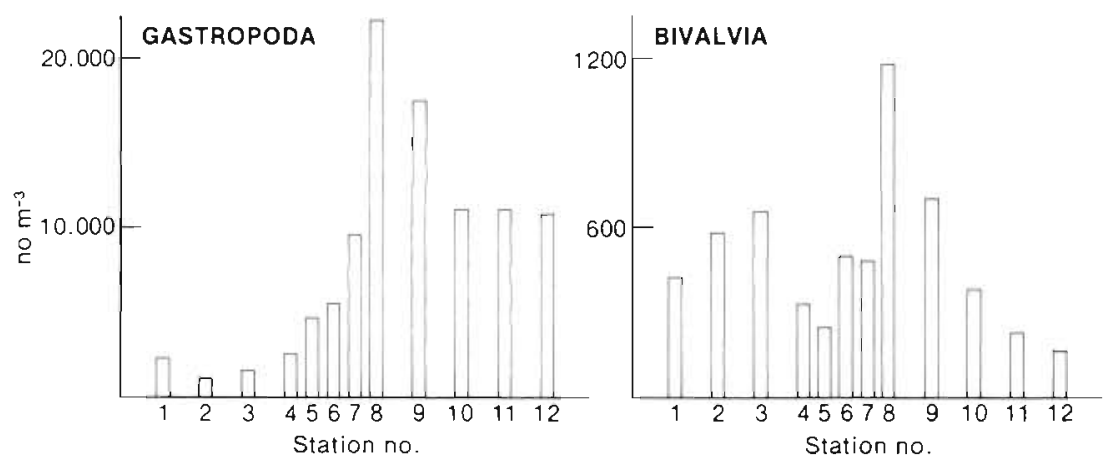

Fig. 6. Distribution of gastropods and bivalve veligers along Transect 1 (12 to 13 Oct) 

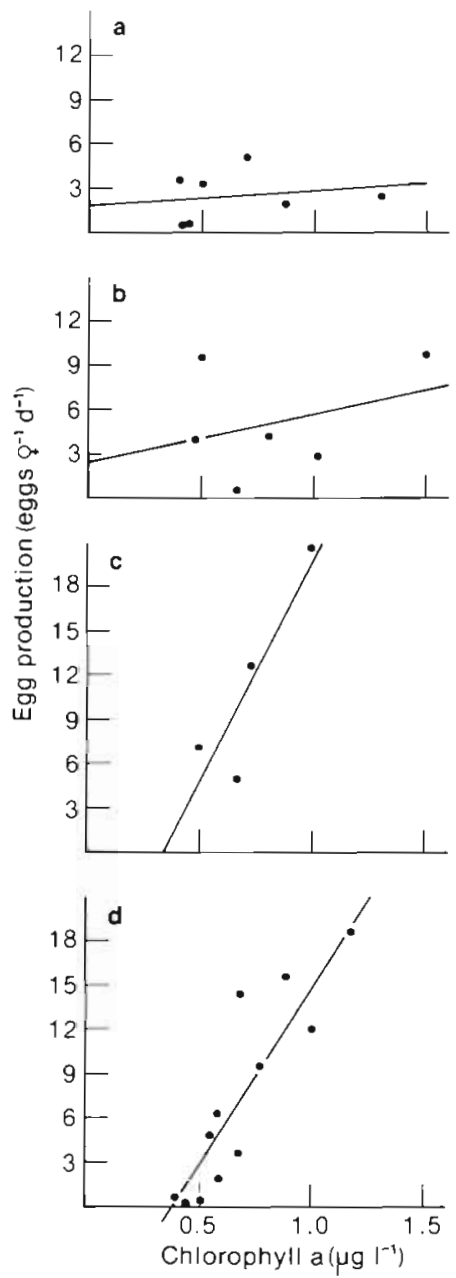

Fig. 7. Acartia tonsa. Relationship between experimentally determined egg-production rates $\left(E_{i}\right.$ eggs female $\left.{ }^{-1} d^{-1}\right)$ and concentration of chlorophyll a $\left(\mathrm{CHL}_{i} \mu \mathrm{g} \mathrm{I}^{-1}\right)$ at the collection depth over 4 consecutive periods. (a) 8 to 10 Oct; regression: $E=1.81+1.01 \mathrm{CHL}, r=0.19$. (b) 12 to 13 Oct $E=2.61+$ $3.15 \mathrm{CHL}, r=0.32$. (c) 14 to 15 Oct; $\mathrm{E}=-10.6+30.3 \mathrm{CHL}, r=$ 0.89. (d) 16 to $17 \mathrm{Oct}$; $\mathrm{E}=-9.4+24.1 \mathrm{CHL}, r=0.87$

tially surveyed during Surveys 1 to 4 . Although considered in the calculations, they will not be dealt with further in the text.

At the beginning of the study, hatching still occurred to Cohorts 1 and 2 . This was indicated by the continued presence of significant numbers of small (ca $7 \mathrm{~mm}$; length at hatching $6.7 \mathrm{~mm}$ ) larvae until Survey 1 (Cohort 1) and Survey 2 (Cohort 2). From Survey 3 onwards all larvae were $>9 \mathrm{~mm}$.

Centres of larval distributions (Fig. 8f) occurred in (Cohorts 2 to 5) or close to (Cohorts 1 and 6) frontal waters, and were, in all cases, confined to within $\Phi<30 \mathrm{~J} \mathrm{~m}^{-3}$ (cf. Fig. 3). Significant concentrations of larvae were not encountered in the strongly stratified waters east of $\mathrm{ca} 0^{\circ}$. The drift trajectories (Fig. 8f) suggest a net southward movement of larval patches at a speed of 2 to $4 \mathrm{~km} \mathrm{~d}^{-1}$. Cohorts with centres on the immediate mixed side of the front (Cohorts 1 and 6 ) tended to move faster than cohorts with centres in frontal water. Cohort 2, in particular, seemed to be retained at the 'southern' front for a prolonged period and the driftspeed of Cohort 1 tended to slow down as it approached the frontal water here.

Thus, larvae tended to concentrate in the front. This is also evident in the cross-frontal transects (Fig. 4b, h), where larval densities in both cases peaked in the transition zone between isothermal and temperaturestratified water.

From estimates of drift speed and direction (Fig. 8f) and growth rates (see below), it is possible to calculate the approximate position of the larval cohorts at the time of hatching (hatching length $6.7 \mathrm{~mm}$ ) and, thus, to identify the spawning grounds (Fig. 8f). Cohorts 3 to 5 apparently stem from a common spawning ground (at Turbot Bank), whereas the other larval cohorts originate from 3 different spawning grounds (Cohort 1: off Aberdeen; Cohort 2: Marr Bank; Cohort 6: off Buchan Ness). These banks are well-known spawning grounds for North Sea herring (Saville 1971).

\section{Larval growth and mortality}

Peak abundances of larvae in cohort centres declined during the study period from $>1000 \mathrm{~m}^{-2}$ during Survey 0 to $<150 \mathrm{~m}^{-2}$ during Survey 4 . This was partly due to larval dispersion and partly to mortality. The mortality rate was estimated from the decline in total larval abundance in each cohort over time. Cohorts 3 to 5 were treated together. Larval abundance was either constant (Cohort 6) or declined exponentially over time (all other cohorts) (Fig. 9). Estimated instantaneous mortalities were similar between cohorts $\left(m=0.03\right.$ to $\left.0.05 \mathrm{~d}^{-1}\right)$, with the exception of Cohort $6\left(m=-0.002 \mathrm{~d}^{-1}\right)$ (Table 2).

Growth in length was apparently constant over time (Fig. 10). Length versus time data were, therefore, treated by linear regression, although curvilinear relations fitted the data equally well. Growth rates ranged between 0.13 and $0.24 \mathrm{~mm} \mathrm{~d}^{-1}$ (Table 3). There was no apparent relationship between growth rate and position of the cohort (i. e. mixed versus frontal water) but growth tended to increase with larval size.

\section{DISCUSSION}

\section{Plankton dynamics}

The relationship between spatial and temporal variation in water column stability and phytoplankton biomass and production is well documented in the litera- 


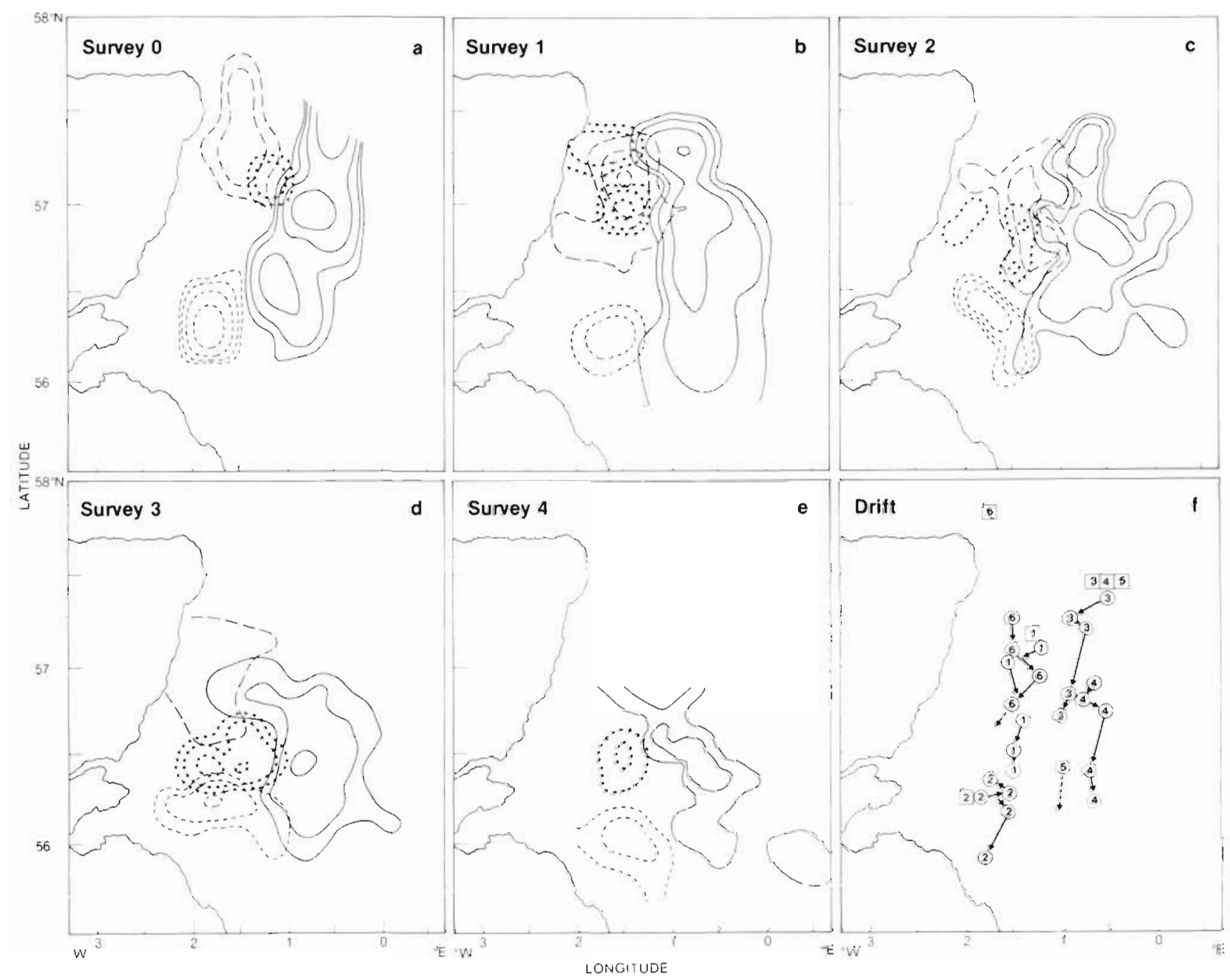

Fig. 8. Clupea harengus. (a to e) Spatial distributions of larval cohorts on 5 consecutive surveys (Survey 0:7 to 9 Sep; Survey $1: 16$ to $21 \mathrm{Sep}$; Survey 2: 23 to $28 \mathrm{Sep}$; Survey 3: 8 to 12 Oct; Survey $4: 17$ to 19 Oct). Symbols: (t+;++) Cohort 1; ( - - -) Cohort 2; ( Cohort $3+4+5 ;(---)$ Cohort 6 . For Surveys 0 to 2, the outermost isolines represent 100 larvae $\mathrm{m}^{-2}$ and towards patch centres, isolines are 200,400 and up to 800 larvae $\mathrm{m}^{-2}$. For Surveys 3 and 4 , the outermost isolines represent 50 larvae $\mathrm{m}^{-2}$ and towards centres, 100 and up to 200 larvae $\mathrm{m}^{-2}$ (f) Movements of cohort centres over time. Numbers refer to the estimated positions of spawning grounds (squares) and cohort centres (circles) of the individual cohorts (see text for estimation procedure). Arrows indicate drift routes. Cohort 6 could not be traced after Survey 3, nor Cohort 5 after Survey 0 (dashed arrows indicate expected routes)

ture: phytoplankton blooms are expected to develop at stratification-destratification interfaces due to a favorable combination of light and nutrients (see e.g. reviews by Legendre 1981, Loder \& Platt 1985). The distributions of chlorophyll and primary production along the 2 frontal transects fit into this generalized picture, with peak biomass and production occurring at the front (cf. Fig. 4).

A storm event may have a similar effect as a front by increasing the depth of the mixed layer and, hence, making new nutrients available to the phytoplankton. Primary production can, therefore, be expected to increase after a storm (e.g. Therriault et al. 1978,
Legendre 1981, Demers et al. 1986, Hitchcock et al. 1987, Wroblewski \& Richman 1987). Unfortunately, no transects were sampled prior to the storm in the present study. Thus, no comparisons can be made to pre-storm conditions. However, between the 2 transects the surface-to-bottom temperature difference declined in both the frontal area and, less dramatically, in stratified waters. Accordingly, the assimilation index ( $g$ carbon fixed (g chlorophyll $a]^{-1}$ ) for stratified stations concurrently increased (from 2.0 to 2.4 ), although the difference was not statistically significant.

Much less is known about zooplankton than phytoplankton distribution and activity in relation to changes 


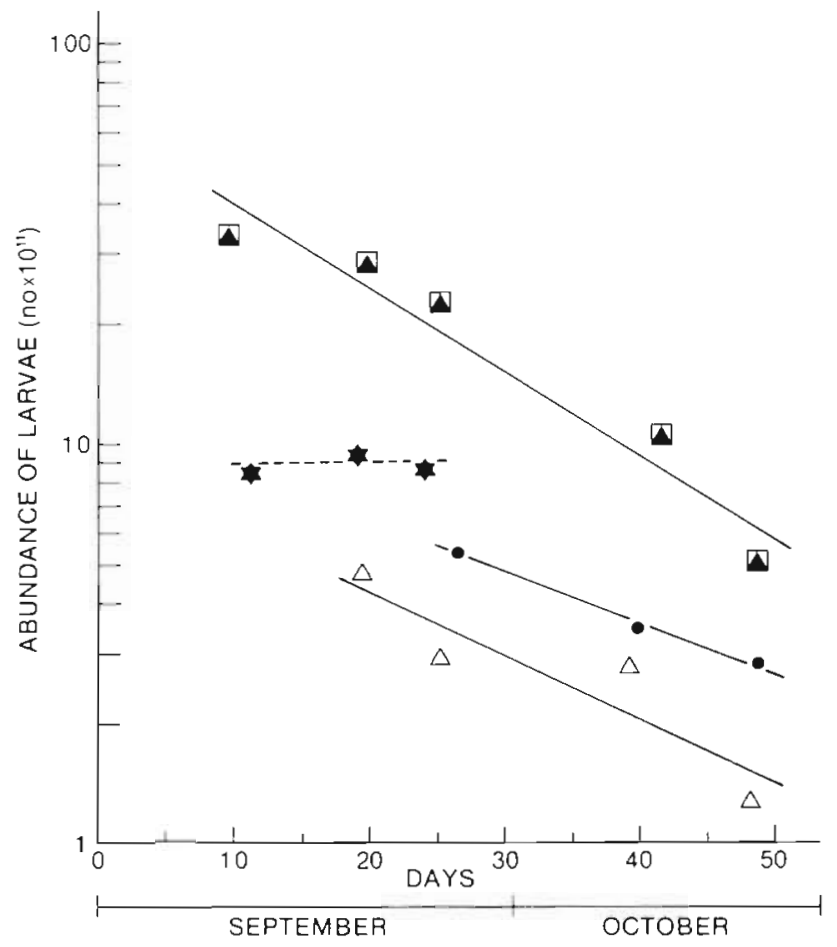

Fig. 9. Clupea harengus. Decline over time in estimated total abundance of larvae in Cohorts $(\Delta) 1,(\bullet) 2,(\Delta) 3$ to 5 , and $(*)$ 6 . Estimated exponential rates of decline (instantaneous mortalities) are given in Table 1

in water column stratification. The present data suggest that copepod grazing and growth (egg production) respond in a similar way as phytoplankton: i.e. increased egg production (and hence, grazing) at stratification-destratification interfaces. This is particularly evident along the frontal transects, where Acartia tonsa egg production peaked concurrently with peak phytoplankton biomass at the front (Fig. 4)

However, Acartia tonsa also responded to the storm event by increasing its rate of egg production, even

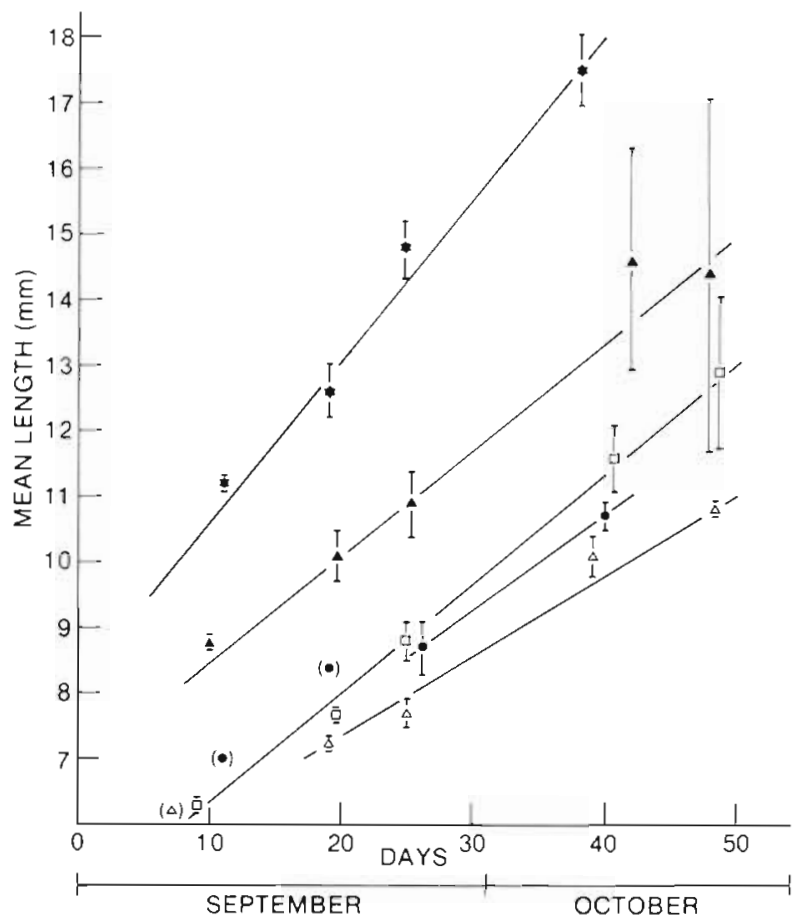

Fig. 10. Clupea harengus. Estimated time course of mean ( $\pm \mathrm{SE}$ ) lengths of larvae in Cohorts $(\Delta) 1,(\bullet) 2,(\square) 3,(\Delta) 4$ and (*) 6 . Points in parenthesis have not been included in regressions since additional hatching may have taken place after the survey. Slopes of the linear regressions are given in Table 2

though the phytoplankton biomass (in terms of chlorophyll) declined (Fig. 7). This can only be explained if the storm-generated turbulent mixing per se stimulated zooplankton grazing (cf. Alcaraz et al. in press) or if the input of nutrients to the surface layer made the algae more edible to the copepods either in terms of size distribution (cf. Peterson \& Bellantoni 1987) or chemical composition (e.g. Goldman 1980). There is not much data relating zooplankton activity

Table 2. Clupea harengus. Estimated larval abundance in different cohorts during period of investigation. Estimation procedure as described in text. In 4 cases (marked with dashes) the cohort distribution was not sufficiently clearly defined for use of the present estimation procedure. Mean time measured in days since 1 September (arbitrary reference date). Mortality estimates from regression of $\ln$ (abundance) versus time. Because of continuous hatching of Cohort 2 between Survey 1 and 2 the estimate at Survey 1 (asterix) is excluded from the regression

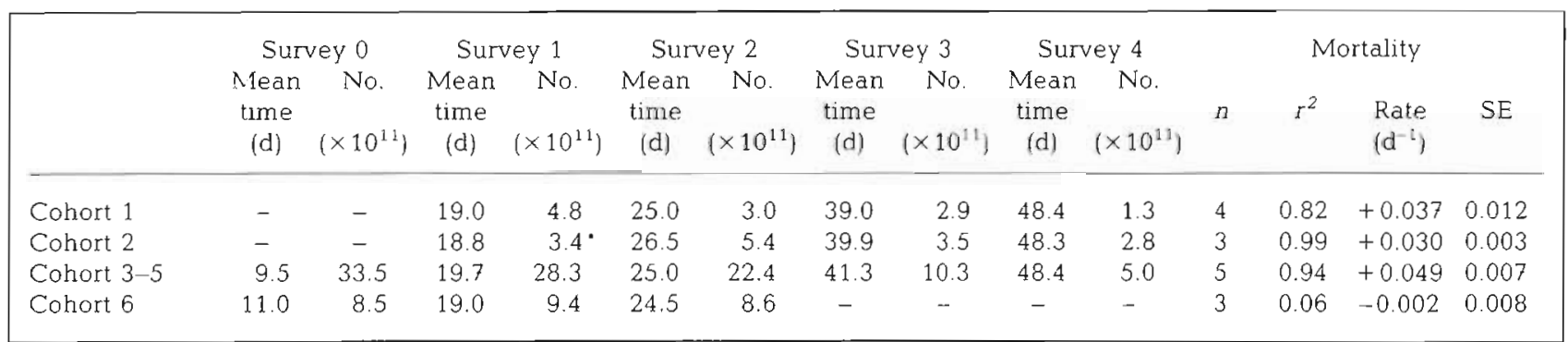


Table 3. Clupea harengus. Estimated mean lengths of larvae in different cohorts during period of investigation. Estimation procedure as described in text. In 6 cases (dashes) the central areas of cohorts could not be identified and thus larval mean size could not be estimated. Mean time measured in days since 1 September (arbitrary reference date). Growth rate estimated from regression of mean length versus time. Because of continuous hatching, estimates marked with an asterix have not been included in regression

\begin{tabular}{|c|c|c|c|c|c|c|c|c|c|c|c|c|c|c|c|c|c|c|c|}
\hline & \multicolumn{3}{|c|}{ Survey 0} & \multicolumn{3}{|c|}{ Survey 1} & \multicolumn{3}{|c|}{ Survey 2} & \multicolumn{3}{|c|}{ Survey 3} & \multicolumn{3}{|c|}{ Survey 4} & \multicolumn{4}{|c|}{ Growth } \\
\hline & $\begin{array}{l}\text { Mean } \\
\text { tıme } \\
\text { (d) }\end{array}$ & $\begin{array}{l}\text { Mean } \\
\text { size } \\
(\mathrm{mm})\end{array}$ & $\begin{array}{c}\mathrm{s}^{2} \\
\left(\mathrm{~mm}^{2}\right)\end{array}$ & $\begin{array}{c}\text { Mean } \\
\text { time } \\
\text { (d) }\end{array}$ & $\begin{array}{c}\text { Mean } \\
\text { size } \\
(\mathrm{mm})\end{array}$ & $\begin{array}{c}\mathrm{s}^{2} \\
\left(\mathrm{~mm}^{2}\right)\end{array}$ & $\begin{array}{c}\text { Mean } \\
\text { time } \\
\text { (d) }\end{array}$ & $\begin{array}{c}\text { Mean } \\
\text { size } \\
(\mathrm{mm})\end{array}$ & $\begin{array}{c}\mathrm{s}^{2} \\
\left(\mathrm{~mm}^{2}\right)\end{array}$ & $\begin{array}{l}\text { Mean } \\
\text { time } \\
\text { (d) }\end{array}$ & $\begin{array}{c}\text { Mean } \\
\text { size } \\
(\mathrm{mm})\end{array}$ & $\begin{array}{c}\mathrm{s}^{2} \\
\left(\mathrm{~mm}^{2}\right)\end{array}$ & $\begin{array}{c}\text { Mean } \\
\text { time } \\
\text { (d) }\end{array}$ & $\begin{array}{c}\text { Mean } \\
\text { size } \\
(\mathrm{mm})\end{array}$ & $\begin{array}{c}\mathrm{s}^{2} \\
\left(\mathrm{~mm}^{2}\right)\end{array}$ & $n$ & $2 r^{2}$ & $\begin{array}{c}\text { Rate } \\
\left(\mathrm{mm} \mathrm{d}^{-1}\right)\end{array}$ & SE \\
\hline C 1 & 7.0 & $7.2^{\circ}$ & 0.3 & 19.0 & 7.9 & 0.5 & 25.0 & 8.7 & 0.9 & 39.0 & 11.1 & 1.9 & 48.4 & 11.8 & 0.4 & 4 & 0.99 & 0.13 & 0.01 \\
\hline C 2 & 11.0 & $8.0^{\circ}$ & 0.4 & 18.8 & $9.4^{\circ}$ & 1.6 & 26.5 & 9.7 & 2.0 & 39.9 & 11.7 & 1.0 & - & - & - & 2 & - & 0.15 & 0.01 \\
\hline C 3 & 9.0 & 7.3 & 0.4 & 19.5 & 8.7 & 1.2 & 24.8 & 9.8 & 1.5 & 40.7 & 12.6 & 2.2 & 48.7 & 13.9 & 3.3 & 5 & 0.99 & 0.16 & 0.01 \\
\hline $\mathrm{C}_{4}$ & 10.0 & 9.8 & 0.8 & 19.8 & 11.1 & 2.8 & 25.2 & 11.9 & 2.9 & 42.0 & 15.6 & 4.7 & 48.0 & 15.4 & 2.0 & 5 & 0.98 & 0.16 & 0.01 \\
\hline C 5 & 10.0 & 13.5 & 2.4 & - & - & - & - & - & - & - & - & - & - & - & - & & & & \\
\hline C 6 & 11.0 & 12.2 & 1.7 & 19.0 & 13.6 & 3.7 & 24.5 & 15.8 & 4.5 & 38.2 & 18.5 & 3.8 & - & - & - & 4 & 0.98 & 0.24 & 0.02 \\
\hline
\end{tabular}

and water column stability in the literature. However, Kiørboe \& Johansen (1986) also found copepod production to peak in the frontal region of the Buchan area. Hanson et al. (1986) showed zooplankton grazing to increase in response to an upwelling event in the Ria de Arosa, Spain, and Mullin et al. (1985) found that the abundance of copepod nauplii increased in response to a storm event off southern California. A similar result was predicted by the computer model of Wroblewski \& Richman (1987). The available information, thus, suggests that zooplankton activity (grazing, production) peaks at stratification-destratification interfaces, such as those found at fronts or occurring after storm and upwelling events.

Although there may be a relationship between zooplankton production and hydrography, there was no apparent relationship between hydrographic features and the distribution of copepods in this study. Actually, most authors have been unable to relate zooplankton abundance to frontal regions (e. g. Holligan et al. 1984, Kahru et al. 1984, Moal et al. 1985, Richardson 1985). Exceptions are Floodgate et al. (1981) who found peak abundance of copepods across a front in Liverpool Bay (Irish Sea) and Kiørboe \& Johansen (1986) who found that the concentration of copepod eggs could be related to hydrography and distribution of chlorophyll in the Buchan front. However, in the latter study, the distributions of successively older copepod stages were decreasingly related to hydrography. It is possible that the very same physical phenomena that enhance secondary production (frequent autumn storms and the dynamic nature of fronts) may, themselves, prevent any interpretable distributional patterns to evolve in organisms with long generation times $(\sim 1 \mathrm{mo})$. Horizontal and temporal variations in copepod mortality, particularly in the egg stage, may further obscure any phytoplankton-copepod distributional relationships (Kiørboe et al. in press). Thus, even though copepod distribution did not reflect hydrography, the frontal region may be considered to be potentially more productive and thus, more favourable to the survival of herring larvae than waters outside of the frontal region.

\section{Distribution and drift of larvae}

Iles \& Sinclair (1982) considered the vertically isothermal waters bounded by fronts as larval retention areas and thought of larval retention as a mechanism of maintaining stock discreteness. The most consistent feature of the observed larval distributions, from spawning in August-September until our last observation in October, is that the centres of larval distributions remained in or within the front bordering the Buchan area. Although the larvae were transported towards the south, they tended to concentrate at the front itself. Preliminary investigations suggest that this drift pattern is consistent with the tidal residual currents in the area (X. Shen unpubl.) and, thus, not necessarily caused by 'compensatory' vertical movements of the larvae in a 2-layered current system as implicated by Sinclair \& Iles (1985) and shown for some larval populations (e. g. Graham 1972, Fortier \& Leggett 1983). The present data, thus, lend partial support to the retention concept.

However, by February, larvae from the Buchan area are found in the central North Sea (Munk 1986) and the integrity of the retention area is, therefore, limited in time, presumably to the onset of frontal breakdown. The erosion of the front was not very pronounced in October but it is expected to dissolve soon thereafter.

While the mechanism of partial retention of larvae is perhaps simple, there are several possible explanations for the coincidence between fronts and herring spawn- 
ing grounds in addition to the stock discreteness hypothesis of Iles \& Sinclair (1982). Sinclair \& Iles (1985) found the concentration of total zooplankton (>333 $\mu \mathrm{m}$ ) biomass (displacement volume) to be particularly low in larval herring nursery areas, and claimed that these areas were occupied by the larvae due to their oceanographic properties and in spite of their plankton characteristics. The same type of data led O'Boyle et al. (1984) to a similar conclusion for several larval fish species occurring over the banks of the Scotian shelf. However, as pointed out by Frank \& Leggett (1986) and Frank (in press), total zooplankton biomass is an inadequate measure of larval fish food. In fact, Frank (in press) found an inverse correlation between small- and large-sized zooplankters in the area studied by O'Boyle et al. (1984) which led him to the opposite conclusion. In addition, Townsend et al. (1986) described a pattern of larval herring movements in the Gulf of Maine, USA, that bears some resemblance to the Buchan picture but is different from that predicted by the Iles \& Sinclair (1982) model: upon hatching in mixed water, larvae were advected away from the spawning site towards an area that became progressively stratified (front) and richer in food. A similar pattern was reported by Heath \& MacLachlan (1987) for herring larvae off the Hebrides.

Even though the productivity of the present frontal region is based on horizontal and temporal variation in water column stability, it is predictable in several ways. The localization of the temperature front between $0^{\circ}$ and $1^{\circ} \mathrm{W}$ is very similar to that found in September 1984 and is apparently a recurrent phenomenon (Richardson et al. 1986a). Even though the match between peak larval abundance and peak secondary productivity at the second cross-frontal transect was not perfect, this may be the case at other times (Transect 1, see also Kiørboe \& Johansen 1986). Furthermore, frequent autumn storms are predictable in a statistical sense. Several authors have considered storm events detrimental to fish larvae because wind mixing potentially dissipates patches of larval food (e.g. Lasker 1975, 1981, Wroblewski \& Richman 1986, Peterman \& Bradford 1987). However, Mullin et. (1985) did not observe a decrease in the vertical patchiness of fish larval food after a storm passage, and the present study has documented storm-enhanced secondary production. Thus, the timing and localization of herring spawning may potentially be adapted to these features.

There are, however, still other factors that may be equally important in explaining the distribution of herring larvae. For example, bottom types suitable for herring spawning (i. e. gravel beds) may be generally restricted to (tidally) energetic environments ( $c$ f. Cushing 1986) and are in the Buchan area localized in mixed and frontal waters at depths $<70 \mathrm{~m}$ (Rankine 1986).
Also, the bottom temperature is higher by $>3 \mathrm{C}^{\circ}$ in mixed than in stratified water (Fig. 4), allowing more rapid development of herring eggs (Danielsen \& Iversen 1974). We cannot distinguish between these several hypotheses but food-limited growth of the larvae in this area (see below) suggests that elevated productivity at the front may be significant (in an evolutionary sense) in determining larval herring distributions.

\section{Food-limited growth}

The growth of $10 \mathrm{~mm}$ larvae $\left(0.13\right.$ to $0.15 \mathrm{~mm} \mathrm{~d}^{-1}$; Table 2), with a prey size spectrum similar to that retained in the 30 to $200 \mu \mathrm{m}$ copepod fraction (Checkley 1982), fits that expected from laboratory experiments (Kiørboe \& Johansen 1986, Kiørboe \& Munk $1986)$ but is significantly less than potential growth. The maximum growth rate in the laboratory at $8^{\circ} \mathrm{C}$ is ca $7.5 \% \mathrm{~d}^{-1}$ or about $0.25 \mathrm{~mm} \mathrm{~d}^{-1}$ (McGurk 1984, Kiørboe \& Munk 1986, Kiørboe et al. 1987). Assuming a $Q_{10}$ for growth of 2.3 (Checkley 1984) and allowing for 20\% shrinkage due to capture and preservation, this corresponds to ca $0.28 \mathrm{~mm} \mathrm{~d}^{-1}$ growth in preserved length at $12^{\circ} \mathrm{C}$. Maximum growth rates in natural populations are generally of this magnitude (McGurk 1984, Kiørboe \& Munk 1986 and references therein), although springspawned larvae tend to achieve higher rates of growth (Marshall et al. 1937, Øiestad \& Moksness 1981, Gamble et al. 1985). Only the largest larvae in the present study approached the maximum growth rate which suggests that the majority of the larvae were limited by food availability at this time.

If the larvae are limited by food availability, one would expect a correlation between food concentration and growth rate. This expectation could not be tested using our data but such relationships have recently been studied for natural fish larval populations by means of high frequency sampling (Frank \& Leggett 1986) or the application of alternative techniques to estimate recent growth (Buckley 1984, Govoni et al. 1985, Buckley \& Lough 1987). In all cases, growth rate was shown to depend on in situ food concentration, which in turn suggests food limitation. This is further supported by the observations of Parmanne \& Sjöblom (1982) of a strong correlation of larval food and subsequent recruitment ( 0 -group) in Baltic herring.

The shape of the stock-recruitment relation for North Sea and other herring stocks suggest that recruitment is density-dependent regulated (e.g. Winters \& Wheeler 1987). If the small larvae are limited by food availability, we may further ask to what extent larval feeding influences the amount of available food and, thus, whether larval competition may constribute to density 
dependent recruitment. Cushing (1983) considered intraspecific competition unlikely in young haddock and plaice larvae, as their concentration is too dilute. The case may be somewhat different for demersal spawners like herring, because there is no drift and dispersal phase prior to hatching, and the initial larval concentration is high.

In estimating larval grazing pressure, we utilize the transect data together with laboratory observations on feeding behaviour of herring larvae by Munk \& Kiørboe (1985). They found that a food-limited $12 \mathrm{~mm}$ (live length) herring larvae is able to clear $1.5 \mathrm{l}$ of water of food particles per h. Assuming that 'clearance' (i. e. the imaginary volume of water cleared of food particles per unit time) increases with the cube of larval length (Blaxter \& Hunter 1982), it is possible to estimate larval grazing pressure from the density and size of the larvae. This can be expressed as clearance $\times$ concentration of larvae $x$ day length and is an estimate of the instantaneous prey mortality due to herring larval predation. Note that the above arguments are independent of a detailed knowledge of the diet of the larvae.

On both transects, the estimated instantaneous rates of prey mortality follow, of course, larval abundance and ranged from $0.01 \mathrm{~d}^{-1}$ at low larval concentration to between 0.1 and $0.4 \mathrm{~d}^{-1}$ at peak larval stations. This is much less than the mortality of copepod eggs estimated from measured egg production rates and the ratio of eggs to females in the water column (up to $3.2 \mathrm{~d}^{-1}$, small-sized species combined; Kiørboe et al. in press) and consistont with the fact lillat egg-mortality was unrelated to larval abundance $(r=0.36, p>0.10)$. It is also somewhat less than the turnover rate of copepod eggs estimated from their hatching time (taken to be $2.5 \mathrm{~d}$ at $12^{\circ} \mathrm{C}$ for all species, i. e. [incubation time] ${ }^{-1}$ ). However, it is of the same order of magnitude as turnover rates (i.e. $P / B=$ production to biomass ratios) of nauplii and copepodites, the main larval food. Specific egg production rates of female copepods may be considered a maximum estimate of the specific growth rate (i.e. $P / B$ ) of nauplii and copepodites (Berggreen et al. in press). Measured specific egg production rates of Acartia tonsa varied between 0 and $0.25 \mathrm{~d}^{-1}$. If we consider $A$. tonsa as being representative for larval food organisms, larval grazing is of the same order of magnitude as the production of food, or even higher, since peak larval abundance did not always coincide with peak copepod production. Indeed, at 11 of the 16 stations where we had simultaneous estimates of prey mortality due to herring larvae and specific egg production in $A$. tonsa, the former was equal to or exceeded the latter. At the remaining 5 stations, prey mortality was still a significant fraction of specific productivity $(16$ to $70 \%, \overrightarrow{\mathrm{x}}=$ $42 \%$ ). This is consistent with the negative correlation between larval abundance and proportion of biomass of small-sized ( 30 to $200 \mu \mathrm{m}$ ) copepods to total copepod biomass. We therefore conclude that herring larvae in the patch centres of the Buchan area influence the density of their own food and, thus, potentially compete for food. This, in turn, implies density-dependent growth and, hence, cumulative mortality of larval herring (Shepard \& Cushing 1980, Houde 1987).

Winters \& Wheeler (1987) suggested that densitydependent regulation of herring recruitment was caused mainly by 'competition' for spawning grounds and density-dependent mortality of the eggs. The temporal (and spatial) segregation between cohorts of larvae (and spawnings) was interpreted by Lambert (1984) as an adaptation to competition for food. However, it may equally well be seen as an adaptation to a limitation of suitable spawning grounds. The size segregation between Cohorts 3 to 5, apparently originating from the same spawning ground, was 2.4 $\mathrm{mm}$ (Cohorts 3 to 4 ) and $3.8 \mathrm{~mm}$ (Cohorts 4 to 5), and thus very similar to the average of $3.4 \mathrm{~mm}$ found for herring by Lambert (1984). Utilizing the growth rates in Table 3, this corresponds to a time segregation between spawnings of ca $3 \mathrm{wk}$, which is more than the hatching time for herring eggs at $12^{\circ} \mathrm{C}$ (ca $12 \mathrm{~d}$; Danielsen \& Iversen 1974). Limited spawning grounds cannot, however, solely be responsible for densitydependent regulation of recruitment to the North Sea herring stocks, as there is a fair relationship between larval herring production and adult spawning biomass (Anon. 1985, 1986). We have demonstrated that food competition in the larval stage may be operative and we suggest that it may, at least partly, be responsible for the relative stability of recruitment. It does not, however, account for recruitment variability (a factor of 5 in North Sea herring; Ursin 1982). Variable food availability (Pamanne \& Sjöblom 1982), physical processes such as variable integrity of retention area (Iles \& Sinclair 1982) and/or variable drift patterns (Corten 1986) seem likely to lie at the basis of recruitment variability.

Acknowledgements. We thank the officers and crew of RV 'Dana' for help in carrying out this project and the DAFS Marine Laboratory for permission to use their larval herring data (Survey 0).

\section{LITERATURE CITED}

Alcaraz, M., Estrada, M., Marrase, C. (in press). Interaction between turbulence and zooplankton in laboratory microcosms. Proceedings 21st European Marine Biology Symposium, Gdansk 15-19 Sep, 1986. Polish Academy of Sciences

Anonymous (1985). Report of the working group on herring larval surveys south of $62^{\circ} \mathrm{N}$. Coun. Meet. int. Coun. Explor. Sea C. M.-ICES/H: 3 
Anonymous (1986). Report of the working group on herring larval surveys south of $62^{\circ} \mathrm{N}$. Coun. Meet. int Coun. Explor Sea C. M.-ICES/H: 3

Berggreen, U., Hansen, B., Kiørboe, T (in press). Food size spectra, ingestion and growth of the copepod Acartia tonsa during development: implications for the determination of copepod production. Mar. Biol.

Blaxter, J. H. S., Hunter, J. R. (1982). The biology of the clupeoid fishes. Adv. mar. Biol. 20: 1-223

Buckley, L. J. (1984). RNA-DNA ratio: an index of larval fish growth in the sea. Mar Biol. 80: 291-298

Buckley, L. J., Lough, R. G. (1987). Recent growth, biochemical composition, and prey field or larval haddock (Melanogrammus aeglefinus) and Atlantic cod (Gadus morhua) on George Bank. Can. J Fish. aquat. Sci. 44: $14-25$

Checkley, D. M., Jr (1982). Selective feeding by Atlantic herring (Clupeae harengus) larvae on zooplankton in natural assemblages. Mar. Ecol. Prog. Ser. 9: 245-253

Checkley, D. M., Jr (1984). Relation of growth to ingestion for larvae of Atlantic herring Clupea harengus and other fish. Mar Ecol. Prog. Ser. 18: 215-224

Christensen, V., Dahl, E., Danielsen, D. S., Hundahl, H., Kiørboe, T., Kullenberg, G. (1983). A combined fish larval, phytoplankton, and oceanographic survey in the Skaggerak and the Kattegat in April 1983. Coun. Meet. int Coun. Explor Sea C. M.-ICES/L: 26

Corten, A. (1986). On the causes of the recruitment failure of herring in the central and northern North Sea in the years 1972-78. J. Cons. int. Explor. Mer 42: 218-294

Cushing, D. H. (1975). Marine ecology and fisheries. Cambridge University Press, Cambridge

Cushing, D. H. (1983). Are fish larvae too dilute to affect the density of their food organisms? J. Plankton Res. 5: $847-854$

Cushing, D. H. (1986). The migration of larval and juvenile fish from spawning ground to nursery ground. J. Cons. int. Explor. Mer 43: 43-49

Danielsen, D. S., Iversen, S. A. (1974). Egg og larveutvikling hos rødspette (Pleuronectes platessa L.), torsk (Gadus morhua L.) og vårgytende sild (Clupea harengus L.) ved konstante temperaturer Fiskeridir Havforskningsinst. Statens Biol. Stat, Flodevigen. Ser. B, No. 22

Demers, S., Legendre, L., Therriault, J.-C. (1986). Phytoplankton responses to vertical tidal mixing. In: Bowman, $M$. J. Yentsch, D. M., Peterson, W T. (eds.) Tidal mixing and plankton dynamics. Lecture notes on coastal and estuarine studies, Vol. 17. Springer Verlag, Berlin, p. 1-40

Floodgate, C. D., Fogg, G. E., Jones, D. A., Lochte, K., Turley, C. M. (1981). Microbial and zooplankton activity at a front in Liverpool Bay. Nature, Lond. 290: 133-136

Fortier, L., Leggett, W. C. (1983). Vertical migration and transport of larval fish in a partially mixed estuary. Can. J. Fish. Aquat. Sci. 40: 1543-1555

Frank, K. T (in press). Independent distributions of fish larvae and their prey: natural paradox or sampling artefact. Can. J. Fish. aquat. Sci.

Frank, K. T., Leggett, W C. (1986). Effect of prey abundance and size on the growth and survival of larval fish: an experimental study employing large volume enclosures. Mar. Ecol. Prog. Ser. 34: 11-22

Gamble, J. C., MacLachlan, P., Seaton, D. D. (1985). Comparative growth and development of autumn and spring spawned Atlantic herring larvae reared in large enclosed ecosystems. Mar. Ecol. Prog. Ser 26: 19-33

Goldman, J. C. (1980). Physiological processes, nutrient availability, and the concept of relative growth rate in marine phytoplankton ecology. In: Falkowski, P. G. (ed.) Primary production in the sea. Plenum Press, New York, $p$ $179-194$

Govoni, J. J., Chester, A. J., Hoss, D. E., Ortner, P. B. (1985) An observation of episodic feeding and growth of larval Leiostomus xanthurus in the northern Gulf of Mexico. J Plankton Res. 17: 137:146

Graham, J. J. (1972). Retention of larval herring within the sheepscot estuary of Maine. Fish. Bull. U. S. 70: 229-305

Hanson, R. B., Alvarez-Ossorio, M. T., Cal, R., Campos, M. J. Roman, M., Santiago, G., Varela, M., Yoder, J. A. (1986) Plankton response following a spring upwelling event in the Ria de Arosa, Spain. Mar. Ecol. Prog. Ser. 32: 101-113

Heath, M. R., MacLachlan, P., (1987). Dispersion and mortality of yolk-sac herring (Clupea harengus L.) larvae from a spawning ground to the west of the Outer Hebrides. J. Plankton Res. 9: 613-630

Heath, M. R., MacLachlan, P. M., Martin, J. H. A. (1987). Inshore circulation and transport of herring larvae off the north coast of Scotland. Mar. Ecol. Ser. 40: 11-23

Hitchcock, G. L., Langdon, D., Smayda, T. J. (1987). Shortterm changes in the biology of a Gulf Stream warm core ring: phytoplankton biomass and productivity. Limnol. Oceanogr 32: 919-928

Hjort, J. (1914). Fluctuations in the great fisheries of Northern Europe viewed in light of biological research. Rapp. P.-v. Réun. Cons. int. Explor. Mer 20: 1-228

Holligan, P. M., Harris, R. P., Newell, R. C., Harbour, D. S. Head, R. N., Linley, E. A. S., Lucas, M. I., Tranter, P. R. G., Weekley, C. M. (1984). Vertical distribution and partitioning of organic carbon in mixed, frontal and stratified waters of the English Channel. Mar. Ecol. Prog. Ser. 14: $111-127$

Houde, E. D. (1987). Fish early life dynamics and recruitment variability. Am. Fish. Soc. Symp. No. 2: 17-29

Iles, T D., Sinclair, M. (1982). Atlantic herring: stock discreteness and abundance. Science 215: 627-633

Iles, T D., Sinclair, M. (1985). An instance of herring larval retention in the North Sea. Coun. Meet. int. Coun. Explor: Sea C. M.ICES/H: 43

Kahru, M., Elken, J., Kotta, I., Simm, M., Vilbaste, K. (1984). Plankton distributions and processes across a front in the open Baltic Sea. Mar. Ecol. Prog. Ser. 20: 101-111

Kiørboe, T., Johansen, K. (1986). Studies of a larval herring (Clupea harengus L.) patch in the Buchan area. IV Zooplankton distribution and productivity in relation to hydrographic features. Dana 6: 37-51

Kiørboe, T., Møhlenberg, F., Riisgård, H. U. (1985). In situ feeding rates of planktonic copepods: a comparison of four methods. J. exp. mar. Biol. Ecol. 88: 67-81

Kiorboe, T., Munk, P. (1986). Feeding and growth of larval herring, Clupea harengus, in relation to density of copepod nauplii. Environ. Biol. Fish. 17: 133-139

Kiorboe, T., Mohlenberg, F., Tiselius, P. (in press). Propagation of planktonic copepods: production and mortality of eggs. Proc. 3rd Int. Conf. Cop., London 10-14 August, 1987. Hydrobiologia

Kiorboe, T., Munk, P., Richardson, K. (1987). Respiration and growth of larval herring (Clupea harengus): relation between specific dynamic action and growth efficiency. Mar. Ecol. Prog. Ser. 40:1-10

Lambert, T C. (1984). Larval cohort succession in herring (Clupea harengus) and capelin (Mallotus villosus). Can. J. Fish. aquat. Sci. 41: 1552-1564.

Lambert, T. C., Ware, D. M. (1984). Reproductive strategies of demersal and pelagic spawning fish. Can. J. Fish. aquat. Sci. 41 1565-1569 
Lasker, R. (1975). Field criteria for survival of anchovy larvae. The relation between inshore chlorophyll maximum layers and successful first feeding. Fish. Bull. U. S. 73: 453-462

Lasker, R. (1981). Factors contributing to variable recruitment of the northern anchovy (Engraulis mordax) in the California Current: contrasting years 1975 through 1978. Rapp. P.-v. Réun. Cons. int. Explor. Mer 178: 375-388

Legendre. L. (1981). Hydrodynamic control of marine phytoplankton production: the paradox of stability. In: Nihoul, J. C. J. (ed.) Ecohydrodynamics. Elsevier, Amsterdam, p. $109-207$

Loder, W. J., Platt, T. (1985). Physical controls on phytoplankton production at tidal fronts. In: Gibbs P. E. (ed.) Proceedings 19th European Marine Biology Symposium. Cambridge University Press, Cambridge, p. 3-19

Marshall, S. M., Nicholls, A. G., Orr, A. P. (1937). On the growth and feeding of the larvae and post-larval stages of the Clyde herring. J. mar. biol. Ass. U. K. 22: 345-267

McGurk, M. D. (1984). Effects of delayed feeding and temperature on the age of irreversible starvation and on the rates of growth and mortality in Pacific herring larvae. Mar. Biol. $84: 13-26$

Moal, J., Samain, J. F., Kontsikopoulus, C., Coz, J. R. Le, Daniel, J. Y. (1985). Ushant thermal front: digestive enzymes and zooplankton production. In: Gibbs P. E. (ed.) Proceedings 19th European Marine Biology Symposium. Cambridge University Press, Cambridge, p. 145-156

Mullin, M. M., Brooks, E. R., Reid, F. M. H., Napp, J., Stewart, E. F. (1985). Vertical structure of nearshore plankton off southern California: a storm and a larval fish food web Fish. Bull. U. S. 83: 151-170

Munk, P. (1986). The distribution of 6-month-old herring larvae in the North Sea. Coun. Meet. int. Coun. Explor Sea C. M.-ICES/L: 34

Munk. P., Christensen, V., Paulsen, H. (1986). Studies of a larval herring (Clupea harengus L.) patch in the Buchan area. II. Growth, mortality and drift of larvae. Dana 6: $11-24$

Munk, P., Kiørboe, T (1985). Feeding behaviour and swimming activity of larval herring (Clupea harengus L.) in relation to density of copepod nauplii. Mar. Ecol. Prog. Ser. 24: $15-21$

O'Boyle, R. N., Sinclair, M., Conover, R. J., Mann, K. H., Kohler, A. C. (1984). Temporal and spatial distribution of ichthyoplankton communities of the Scotian Shelf in relation to biological, hydrological, and physiographic features. Rapp. P.-v. Réun. Cons, int. Explor. Mer 183: $27-40$

Øiestad, V., Moksness, E. (1981). Study of growth and survival of herring larvae (Clupea harengus L.) using plastic bags and concrete basin enclosures. Rapp. P.-v. Réun, Cons. int. Explor. Mer 178: 144-149

Parmanne, R., Sjöblom, V (1982). The abundance of spring spawning baltic herring larvae in the seas around Finland in 1981 and the effect of zooplankton abundance on the herring class strength. Coun. Meet. int. Coun. Explor. Sea C. M.-[CES/J: 17

Peterman, R. M., Bradford, M. J. (1987). Wind speed and mortality rate of a marine fish, the northern anchovy (Engraulis mordax). Science 235: $354-356$

Peterson, W. T., Bellantoni, D. C. (1987). Relationship between hydrodynamics, phytoplankton cell size and copepod fecundity. S. Afr. J. mar. Sci. 5: 411-421

Pingree, R. D., Griffiths, D. K. (1978). Tidal fronts on the shelf seas around the British Iles. J. geophys. Res. 83: $4615-4622$

Rankine. P. W (1986). Herring spawning grounds around the Scottish coast. Coun. Meet. int. Coun. Explor. Sea C. M.ICES/H: 15

Richardson, K. (1985). Plankton distribution and activity in the North Sea/Skagerrak-Kattegat frontal area in April 1984. Mar Ecol. Prog. Ser. 26: 233-244

Richardson, K., Heath, M. R., Pihl, N. J. (1986a). Studies of a larval herring (Clupea harengus L.) patch in the Buchan area. I. The distribution of larvae in relation to hydrographic features. Dana 6: 1-10

Richardson, K., Heath, M. R., Pedersen, S. M. (1986b). Studies of a larval herring (Clupea harengus L.) patch in the Buchan area. III. Phytoplankton distribution and primary productivity in relation to hydrographic features. Dana 6: 25-36

Ricker, W. E., Foerster, R. E. (1984). Computation of fish production. Bull. Bingham oceanogr. Coll. 11: 173-211

Saville, A. (1971). The distribution and abundance of herring larvae in the northern North Sea, changes in recent years. Rapp. P.-v. Réun. Cons. Perm. int. Explor. Mer 160:87-93

Shepard, J. G., Cushing, D. H. (1980). A mechanism for density-dependent survival of larval fish as the basis for a stock-recruitment relationship. J. Cons. int. Explor. Mer 39: $160-167$

Simpson, J. H. (1981). The shelf-sea fronts: implications of their existence and behaviour Phil. Trans. R. Soc. Lond. 302 (A) : $531-546$

Sinclair, M., Iles, T. D. (1985). Atlantic herring (Clupea harengus) distributions in the Gulf of Maine-Scotian shelf area in relation to occunogyaphin featules. Can. J. Fish. Aquat. Sci. 42: 880-887

Therriault, J.-C., Lawrence, D. J., Platt, T (1978). Spatial variability of phytoplankton turnover in relation to physical processes in a coastal environment. Limnol. Oceanogr. 23: $900-911$

Townsend, D. W., Graham, J., Stevenson, D. K. (1986). Dynamics of larval herring (Clupea harengus L.) production in tidally mixed waters of the eastern coastal Gulf of Maine. In: Bowman, M. J., Yentsch, C. M., Peterson, W. T. (eds.) Tidal mixing and plankton dynamics. Lecture notes on coastal and estuarine studies, Vol. 17. Springer-Verlag, Berlin, p. 253-277

Ursin, E. (1982). Stability and variability in the marine ecosystem. Dana 2: $51-67$

Winters, G. H., Wheeler, J. P. (1987). Recruitment dynamics of spring-spawning herring in the Northwest Atlantic. Can. J. Fish. aquat. Sci. 44: 882-900

Wroblewski, J. S., Richman, J. G. (1987). The nonlinear response of plankton to wind mixing events: implications for survival of larval northern anchovy. J. Plankton Res. 9: $103-123$ 